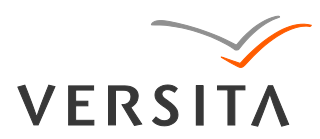

GEOCHRONOMETRIA 41(4) 2014: 342-351

DOI 10.2478/s13386-013-0169-7

Available online at

www.springerlink.com

\title{
COMPARING DIFFERENT POST-IR IRSL APPROACHES FOR THE DATING OF HOLOCENE COASTAL FOREDUNES FROM RUHNU ISLAND, ESTONIA
}

\author{
FRANK PREUSSER ${ }^{1}$, MERLE MURU ${ }^{2}$ and ALAR ROSENTAU ${ }^{2}$ \\ ${ }^{I}$ Department of Physical Geography and Quaternary Geology, Stockholm University, 10691 Stockholm, Sweden \\ ${ }^{2}$ Institute of Ecology and Earth Sciences, Ravila 14A, 50411 Tartu, Estonia
}

Received 12 December 2013

Accepted 27 May 2014

\begin{abstract}
Different post-IR Infrared Stimulated Luminescence (IRSL) approaches are applied to sediments from a Holocene coastal foredune sequence on Ruhnu Island in the eastern Baltic Sea. The comparison of $D_{\mathrm{e}}$-values and ages determined by the different approaches is complimented by fading and bleaching experiments. The fading experiments imply strong fading of IRSL $\left(50^{\circ} \mathrm{C}\right)$ signals and no fading of any of the post-IR IRSL signals, but this is not confirmed by the determined $D_{\mathrm{e}}$-values. In fact, post-IR IRSL $\left(150^{\circ} \mathrm{C}\right) D_{\mathrm{e}}$-values agree within errors with those calculated for IRSL $\left(50^{\circ} \mathrm{C}\right)$. From the bleaching experiments it is inferred that the higher values observed for post-IR IRSL at more elevated stimulation temperatures $\left(225^{\circ} \mathrm{C} / 290^{\circ} \mathrm{C}\right)$ are likely related to either thermal transfer and/or slow-to-bleach components within the signal. For the dating of the Holocene foredune sequence of Ruhnu Island, the post-IR IRSL $\left(150^{\circ} \mathrm{C}\right)$ approach is preferred and these agree with the limited independent age control available from radiocarbon dating. Accordingly, the sequence formed between $c a$. $7.0 \mathrm{ka}$ and $2.5 \mathrm{ka}$ ago.
\end{abstract}

Keywords: luminescence, post-IR IRSL, foredunes, Holocene, Baltic Sea.

\section{INTRODUCTION}

Luminescence dating is now regularly used for the dating of Quaternary sediments. While quartz has usually been the mineral of choice in particular for samples of Holocene age, several studies have reported poor luminescence properties of quartz that make it unsuitable for dating (e.g. Preusser et al., 2006; Steffen et al., 2009). When quartz is not suitable for dating, feldspar offers an alternative by utilising Infrared Stimulated Luminescence (IRSL) emitted from this mineral. The major problem of feldspar IRSL is that the luminescence signal is known to suffer from instability, which will lead to underestimation

Corresponding author: F. Preusser

e-mail: frank.preusser@natgeo.su.se of the determined Equivalent Dose $\left(D_{\mathrm{e}}\right)$ and hence the luminescence age of a sample. This phenomenon is known as (anomalous) fading (Wintle, 1973). While approaches to detect and correct for fading have been suggested (e.g. Huntely and Lamothe, 2001), such corrections are not always straightforward (e.g. Wallinga et al., 2007). An alternative would be using feldspar signals that do not suffer from fading and Thomsen et al. (2008) suggested the measurement of IRSL at elevated temperature after readout of IRSL at $50^{\circ} \mathrm{C}$. This approach is known as post-IR IRSL and different stimulation temperatures have been suggested in the past few years (e.g. $225^{\circ} \mathrm{C}$, Buylaert et al., 2009; $290^{\circ} \mathrm{C}$, Thiel et al., 2011; $180^{\circ} \mathrm{C}$ Reimann et al., $2011 ; 150^{\circ} \mathrm{C}$, Madsen et al., 2011; multiple elevated temperature approach, $\mathrm{Li}$ and $\mathrm{Li}, 2011$ ). 
While the stability of the IRSL signal appears to increase with higher stimulation temperatures, this also causes an increase in residual levels observed after artificial daylight exposure, which can cause significant overestimation of the $D_{\mathrm{e}}$, if this is not corrected for. These residuals could either origin from thermal transfer of nonbleachable charge into light-sensitive traps and/or from a contribution of slow-to-bleach traps (Jain and Ankjærgaard, 2011). This effect differs for samples with different geological background and competes with the signal loss from fading. Furthermore, residuals will be more important in samples with low $D_{\mathrm{e}}$ values, i.e. in young (Holocene) samples, and Reimann and Tsukamoto (2012) recommend the use of low preheat and stimulation temperatures in this context. However, due to the limited experience, it appears necessary to further investigate the performance of different post-IR-IRSL approaches in detail to enable a more secure evaluation of data.

The original aim of this project was to establish the chronology of post-glacial coastal foredune deposition on Ruhnu Island, eastern Baltic Sea, Estonia. As quartz did not delivery Optically Stimulated Lumienscence (OSL) emission significantly above background, we focussed first on investigating the performance of three different post-IR-IRSL protocols for dating the aeolian succession. Determination of $D_{\mathrm{e}}$-values and ages is complemented by experiments investigating fading and residual levels for the different procedures. Besides the information on the chronology of coastal evolution and isostatic uplift of Ruhnun Island, this study also provides some broader implication on the performance of post-IR-IRSL when dating young (Holocene) samples.

\section{STUDY SITE}

Ruhnu Island with an area of about $12 \mathrm{~km}^{2}$ is located in the Gulf of Riga in the SE Baltic Sea (Fig. 1). The island is located at the periphery of the post-glacial rebound zone with present apparent land uplift (relative to the rising global sea level) of less than $1 \mathrm{~mm} \mathrm{a}^{-1}$ (Fig. 1A). This area experienced times of significant Holocene marine/lake transgressions and regressions owing to the melting of the continental ice sheet, the up-damming and drainage of the Baltic basin and glacial isostatic rebound (Andrén et al., 2011). Due to relatively slow land uplift, the last transgression in the area occurred at c. 8.5-7.3 ka ago and was followed by regressive shore displacement which continues until the presence (Veski et al., 2005). The highest position of the Litorina Sea shorelines range from $c .0 \mathrm{~m}$ above present sea level in the southern Gulf of Riga to $c .15 \mathrm{~m}$ in the northern part (Fig. 1B). During the Litorina Sea regression phase, sequences of welldeveloped shore-parallel foredune ridges were formed on Ruhnu Island (Fig. 1C), reflecting relative sea level changes and beach progradation. Foredunes are defined as shore-parallel dune ridges formed on the top of the backshore by aeolian sand deposition within vegetation, with actively forming foredunes occupying a foremost seaward position in the dune system (Hesp, 2002). Hence, the dating of foredunes enables the deciphering of the progradation of the beach sea-wards, and by this allows to indirectly infer the speed of sea level lowering.

Ruhnu Island forms the top of a drumlin-like Devonian sandstone bedrock height probably carved out by glaciers during Quaternary glaciations, with major parts of this landform being presently below water (Fig. 1B). The NW-SE oriented bedrock height is approx. $20 \mathrm{~km}$ long, $10 \mathrm{~km}$ wide and has an elevation of 70-80 m. The Devonian sequence is $138 \mathrm{~m}$ thick and has thin dolomite and clay interlayers (Kala and Einasto, 1979). Bedrock is covered by a thin layer of reddish-grey Late-Weichselian
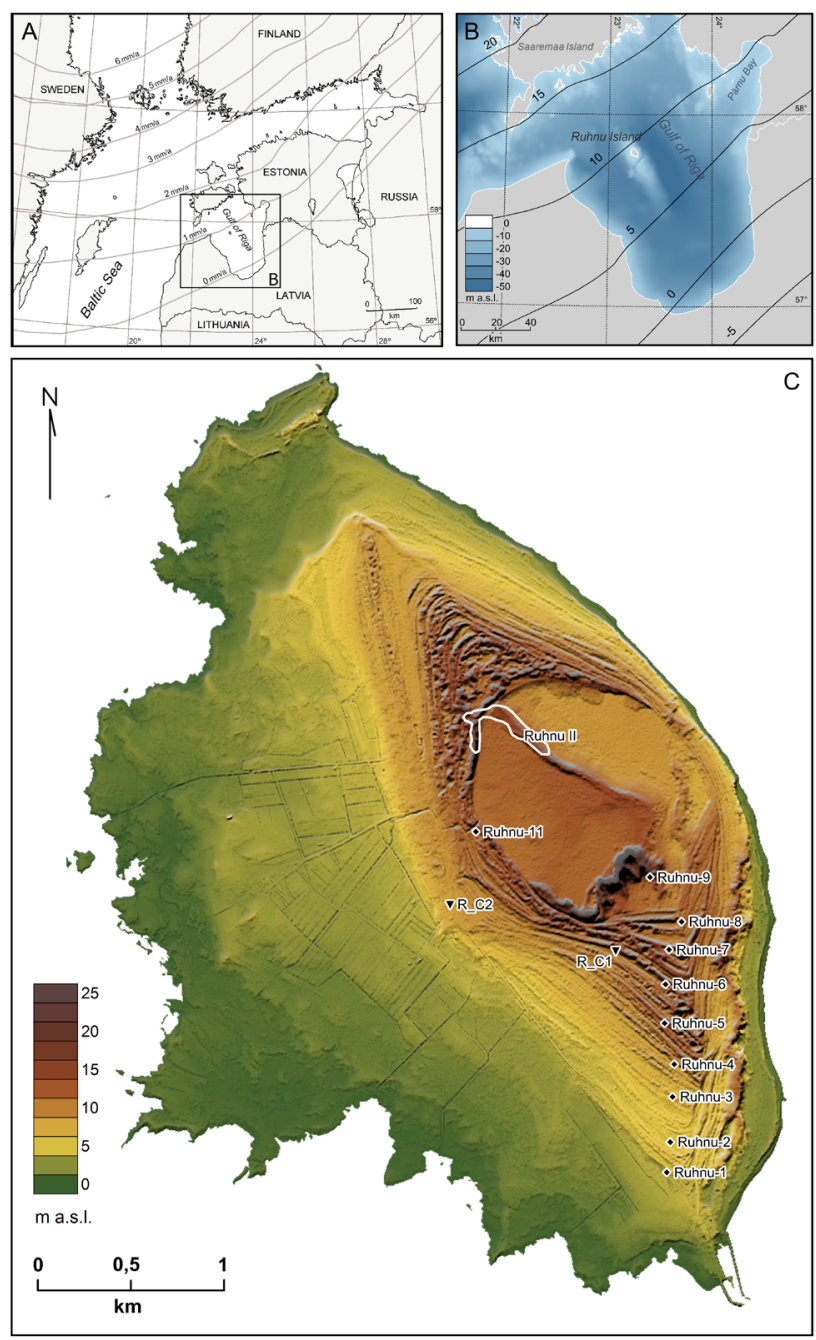

Fig. 1. A) overview map with present-day apparent land uplift isobases after Ekman (1996); B) Bathymetric map of the Gulf of Riga, location of Ruhnu Island and isobases of the Litorina Sea high-stand (m a.s.I.; after Saarse et al., 2003, 2006) approximately 7.3 ka ago; C) Digital elevation model of Ruhnu Island with location of luminescence (Ruhnu1...Ruhnu-11) and radiocarbon sampling sites (Ruhnu II - Mesolithic coastal settlement (Kriiska and Lõugas, 2005); R_C2 - buried oak trunk; $R_{-}$C1 - basal peat in swale). 
till (Kask et al., 1994). In the middle of the central plain on the central ridge, which follows the longer axes of the bedrock height, marine sand and gravel (beach) deposits are occur. Ridge systems consisting of fine sand (foredunes with some re-blown tops) are found around the central plain. The foredune sequences on Ruhnu Island surround the central flat part of the island symmetrically in every direction parallel to former shorelines, by this indicating the shape of the bedrock height. The centremost ridges are the highest and have irregular shapes reflecting evidence of later aeolian processes. Some reblowing is noticeable also in the SE coastal part of the island. Along the western side, the foredunes are located inland because of the gaining of flat dry land on this side of the island, while in the east probably several former foredunes have been eroded by wave action. On the eastern coast the bedrock is exposed in several outcrops and is subject to ongoing erosion (Fig. 1C).

The island is also interesting from an archaeological point of view, as the oldest evidence for a human settlement has been dated by radiocarbon to as old as 7.70$6.85 \mathrm{ka}$ ago. As the island was at that time very distant from the mainland (Fig. 1C), this has raised the question from where and how humans, probably hunter-gatherers following seasonal migration of seals (Phoca hispida), have reached this remote place (Kriiska and Lõugas, 2005).

\section{METHODOLOGY}

The investigated sequence is located on the southwestern foredune plain, which is the widest and most complete sequence on Ruhnu Island (Fig. 1C). Samples for luminescence dating were taken from exposures in artificial ditches and from an outcrop (Ruhnu-11) by forcing opaque plastic tubes into the sediment. All samples were collected from the undisturbed sediments to avoid post-depositional mixing by roots etc. or any ef- fects of soil formation processes. Samples Ruhnu-1 to Ruhnu- 8 and Ruhnu- 11 were taken from the shore parallel (foredune) ridges and sample Ruhnu-9 from a sinusoidal re-blown dune ridge. As sample Ruhnu-9 was taken from the high re-blown part of the dune (altitude $15.9 \pm 0.1 \mathrm{~m}$ a.s.1.), its age might be younger than the next seaward sample. The sampling depth was between 1.25 and $3.55 \mathrm{~m}$ and the sampled material was homogeneous fine-grained sand. The altitudes of the samples were taken from high-resolution airborne LIDAR data with a vertical accuracy typically below $20 \mathrm{~cm}$ (provided by the Estonian Land Board).

The sampling tubes were opened under laboratory red-light and the outer parts from the end of the tubes were used for the determination of dose rate relevant elements. The remaining material was dried, sieved $(160$ $250 \mu \mathrm{m}$ ), and subsequently treated with $\mathrm{HCl}$ and $\mathrm{H}_{2} \mathrm{O}_{2}$ to removed carbonate and organic matter. A feldspar and a quartz fraction where enriched using heavy liquid (LST Fast Float ${ }^{\mathcal{O}}$, densities of $2.70 \mathrm{~g} \mathrm{~cm}^{-3}$ and $2.58 \mathrm{~g} \mathrm{~cm}^{-3}$ ) and the latter fraction was etched in $40 \% \mathrm{HF}$ for one hour, followed by $\mathrm{HCl}$ treatment. The dried mineral grains were mounted on stainless steel discs using silicon spray covering an area of about $2 \mathrm{~mm}$.

All measurements were carried out using a Freiberg Instruments lexsyg research luminescence reader (Richter et al., 2013) equipped with a highly homogenous beta source (Richter et al., 2012), delivering $0.057 \mathrm{~Gy} \mathrm{~s}^{-1}$. As first tests showed that quartz from Ruhnu Island does not emit any detectable OSL emissions (Fig. 2A), all further work concentrated on feldspar. Stimulation was by an $850 \mathrm{~nm}$ IR laser with the power set to $250 \mathrm{~mW} \mathrm{~cm}$. Detection was by an ET-9235QB photomultiplier with filter combination of a Schott BG $39(3 \mathrm{~mm})$ and AHF BrightLine HC 414/46 nm interference filter $(3.5 \mathrm{~mm})$; a typical decay curve is displayed in Fig. 2B. Modified versions of the Single-Aliquots Regenerative Dose (SAR) protocol for post-IR-IRSL have been used for $D_{\mathrm{e}}$ deter-
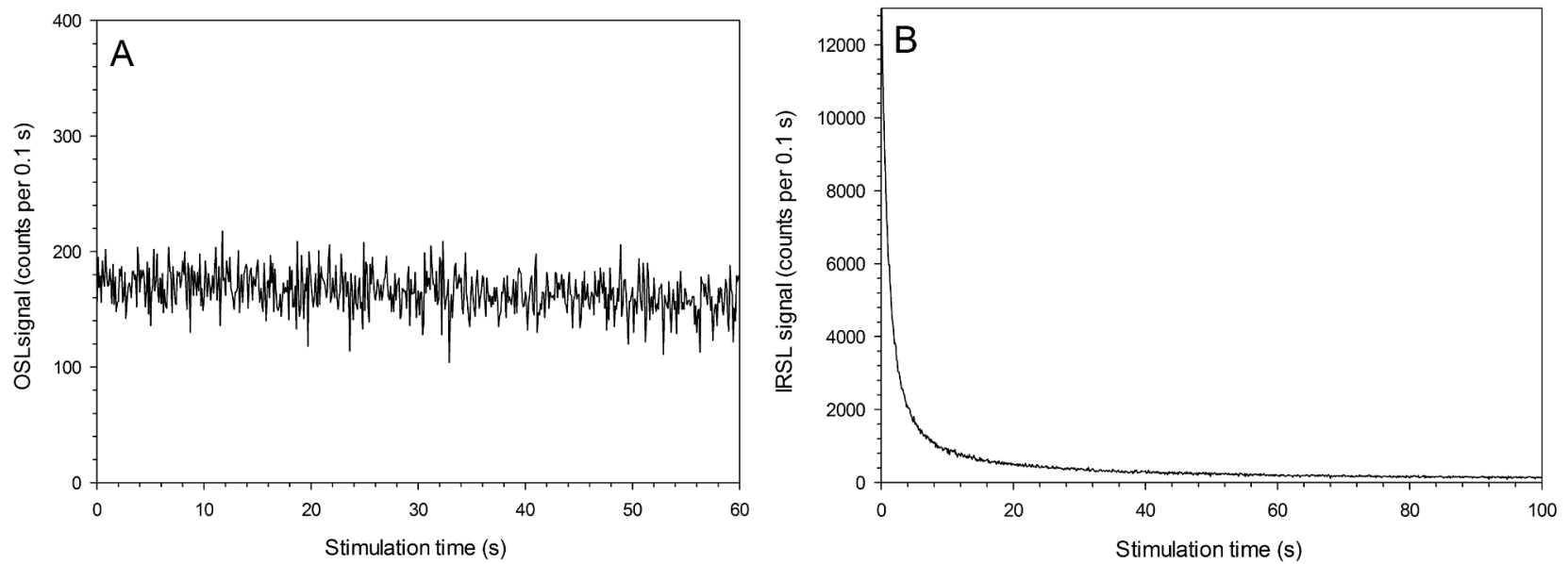

Fig. 2. A) Example of the response of quartz grains from Ruhnu Island to blue light stimulation. B) Typical IRSL decay curve (both for sample Ruhnu-4). 
mination as summarised in Table 1 . Due to the scarcity of feldspar grains in the samples, repeated measurements had to be limited to six (post-IR-IRSL $150^{\circ} \mathrm{C}$ ) and three aliquots (post-IR-IRSL $225^{\circ} \mathrm{C}$ and $290^{\circ} \mathrm{C}$ ). However, due to the good reproducibility (between 5-10\%) this appears acceptable. The samples considered here have bright IRSL and post-IR-IRSL signals and performed generally well during the course of the SAR protocol with recycling ratios near 1.00 and recuperation not exceeding $3 \%$ of the natural signal.

Fading experiments were carried on aliquots of that were previously used for $D_{\mathrm{e}}$ determination to minimise effects of sensitivity change. We followed Auclair et al. (2003) and used delayed $L_{\mathrm{x}} / T_{\mathrm{x}}$ measurements (dosed with $c a$. $5 \mathrm{~Gy}$ ) with preheating prior to storage. The aliquots remained on the measurement arm during storage to avoid potential problems related to sample transport (rotation of the disk, loss of grains). This forced us to limit storage time, i.e. the delay between irradiation and measurement, to 1 and 10 hours to avoid dissipating too much machine time. For a start, we concentrated on one sample (Ruhnu-4) as the samples seem to behave in a similar way.

Bleaching experiments were done fixing nonmeasured sample material on disks and exposing these to daylight (indirect sunlight) in Stockholm in midSeptember (one day $=12$ hours of daylight). We used two different batches, one of which was exposed for two days and the other for seven days of daylight. Due to stable weather condition at that time, we consider the overall daily light level to be more-or-less stable over the entire time period. After daylight exposure, $D_{\mathrm{e}}$ was determined using the same protocols as applied for dating.

For dose rate calculation, the concentration of dose rate relevant elements was determined using low-level high-resolution gamma spectrometry (cf. Preusser and Kasper, 2001). Disequilibrium in the Uranium decay chain was investigated following the procedures described by Zander et al. (2007). We observe indication for radioactive disequilibrium in three of the investigated samples and all represent a loss of Uranium compared to the daughter isotopes. The most common explanation for this would be leaching of carbonates with an associated loss of ${ }^{238} \mathrm{U}$ and ${ }^{234} \mathrm{U}$ in the sediment (cf. Olley et al., 1997). However, the sediments of Ruhnu Island do not contain carbonates excluding this explanation and questioning if the apparent disequilibria are real or an artefact. As the dose rate and age will change by not more than $3 \%$ even when applying extreme scenarios (i.e. rapid loss of Uranium directly after deposition), we will not consider disequilibrium in the discussion of ages. Dose rates and ages were calculated using ADELE software (Kulig, 2005), which uses the dose conversion factors of Adamiec and Aitken (1998) and calculates cosmic dose rate following Prescott and Hutton (1994). Sediment moisture was estimated to be between $4-12 \%$ during burial based on present day water content and a-value of $0.07 \pm 0.02$ has been assumed. All dosimetric data is summarised in Table 2.

\section{RESULTS AND DISCUSSION}

\section{Comparison of different post-IR-IRSL approaches}

Two examples of fading tests are displayed in Fig. 2 for IRSL $\left(50^{\circ} \mathrm{C}\right)$ and post-IR-IRSL of the $150^{\circ} \mathrm{C}$ protocol and the results for all different experiments are summarised in Table 3. The experiments show a good performance with well reproducible $L_{\mathrm{x}} / T_{\mathrm{x}}$ measurements and for all approaches we found a much higher fading rate for IRSL (Fig. 3A) compared to post-IR-IRSL (Fig. 3B). The calculated fading rates are around $5 \%$ per decade for IRSL $\left(50^{\circ} \mathrm{C}\right)$ and around $0 \%$ per decade for the different post-IR-IRSL approaches, very similar to values reported by Reimann and Tsukamoto (2012) for a sample from the southern Baltic Sea (NW Poland). This implies a strong effect of fading on IRSL $\left(50^{\circ} \mathrm{C}\right)$ and no effect on post-IRIRSL. Hence, one would expect that the IRSL ages should be significantly lower than the post-IR-IRSL ages.

Table 4 provides all $D_{\mathrm{e}}$-values and the corresponding ages. None of the values reported have been corrected for fading for the reasons given below. Comparing the different approaches used here first reveals a clear trend in an increased off-set between the IRSL $\left(50^{\circ} \mathrm{C}\right)$ and post-IRIRSL $D_{\mathrm{e}}$-values (and ages) with increasing preheat/stimulation temperature. While the $D_{\mathrm{e}}$-values for IRSL $\left(50^{\circ} \mathrm{C}\right)$ and corresponding post-IR-IRSL $\left(150^{\circ} \mathrm{C}\right)$ are almost identical (Fig. 4A), there is a small difference for the post-IR-IRSL $\left(225^{\circ} \mathrm{C}\right)(\mathrm{Fig} .4 \mathrm{~B})$ and a pronounced off-set for the post-IR-IRSL $\left(290^{\circ} \mathrm{C}\right)($ Fig. 4C) protocols.

Table 1. Overview of SAR protocols used in this study.

\begin{tabular}{cccc}
\hline Step & Post-IR IRSL $\left(150^{\circ} \mathrm{C}\right)$ & Post-IR IRSL $\left(\mathbf{2 2 5} 5^{\circ} \mathrm{C}\right)$ & Post-IR IRSL $\left(290^{\circ} \mathrm{C}\right)$ \\
\hline 1 & Preheat at $180^{\circ} \mathrm{C}$ for $30 \mathrm{~s}$ & Preheat at $250^{\circ} \mathrm{C}$ for $60 \mathrm{~s}$ & Preheat at $320^{\circ} \mathrm{C}$ for $60 \mathrm{~s}$ \\
\hline 2 & IR stimulation at $50^{\circ} \mathrm{C}$ for $100 \mathrm{~s}$ & IR stimulation at $50^{\circ} \mathrm{C}$ for $100 \mathrm{~s}$ & IR stimulation at $50^{\circ} \mathrm{C}$ for $200 \mathrm{~s}$ \\
\hline 3 & IR stimulation at $150^{\circ} \mathrm{C}$ for $200 \mathrm{~s}$ & IR stimulation at $225^{\circ} \mathrm{C}$ for $200 \mathrm{~s}$ & IR stimulation at $290^{\circ} \mathrm{C}$ for $200 \mathrm{~s}$ \\
\hline 4 & Test dose & Test dose & Test dose \\
\hline 5 & Preheat at $180^{\circ} \mathrm{C}$ for $30 \mathrm{~s}$ & Preheat at $250^{\circ} \mathrm{C}$ for $60 \mathrm{~s}$ & Preheat at $250^{\circ} \mathrm{C}$ for $60 \mathrm{~s}$ \\
\hline 6 & IR stimulation at $50^{\circ} \mathrm{C}$ for $100 \mathrm{~s}$ & IR stimulation at $50^{\circ} \mathrm{C}$ for $100 \mathrm{~s}$ & IR stimulation at $50^{\circ} \mathrm{C}$ for $100 \mathrm{~s}$ \\
\hline 7 & IR stimulation at $150^{\circ} \mathrm{C}$ for $200 \mathrm{~s}$ & IR stimulation at $225^{\circ} \mathrm{C}$ for $200 \mathrm{~s}$ & IR stimulation at $290^{\circ} \mathrm{C}$ for $200 \mathrm{~s}$ \\
\hline 8 & Dose (to step 1$)$ & Dose (to step 1$)$ & IR stimulation at $325^{\circ} \mathrm{C}$ for $200 \mathrm{~s}$ \\
\hline 9 & & & Dose (to step 1$)$ \\
\hline
\end{tabular}


Table 2. Dosimetric data giving the sampling depth below present day land surface and the concentration of dose rate relevant elements (K, Th, $U$ ). For Uranium, two values are given for the upper (U-238) and lower part (Ra-226) of the decay chain and the comparison of the two imply disequilibrium, i.e. a loss of Uranium for samples Ruhnu-1, 4, and 6. Further given are cosmic dose rate (Dcos) and total dose rate (D).

\begin{tabular}{|c|c|c|c|c|c|c|c|c|c|}
\hline Sample & $\begin{array}{c}\text { Surface altitude } \\
\text { (m a.s.l.) }\end{array}$ & $\begin{array}{c}\text { Depth } \\
\text { (cm) }\end{array}$ & $\begin{array}{c}K \\
(\%)\end{array}$ & $\begin{array}{c}\mathrm{Th} \\
\text { (ppm) }\end{array}$ & $\begin{array}{c}\mathrm{U}(\mathrm{U}-238) \\
\text { (ppm) }\end{array}$ & $\begin{array}{c}\mathrm{U} \text { (Ra-226) } \\
\text { (ppm) }\end{array}$ & Dis. & $\begin{array}{c}D_{\cos } \\
\left(\mathrm{mGy} \mathrm{ka}^{-1}\right)\end{array}$ & $\begin{array}{c}D \\
\left(G^{k} \mathrm{ka}^{-1}\right)\end{array}$ \\
\hline Ruhnu 1 & $4.0 \pm 0.1$ & 125 & $0.84 \pm 0.01$ & $1.47 \pm 0.05$ & $0.18 \pm 0.07$ & $0.41 \pm 0.01$ & loss? & $175 \pm 18$ & $1.83 \pm 0.10$ \\
\hline Ruhnu 2 & $5.5 \pm 0.1$ & 130 & $0.69 \pm 0.01$ & $0.80 \pm 0.04$ & $0.19 \pm 0.06$ & $0.25 \pm 0.02$ & - & $174 \pm 17$ & $1.61 \pm 0.08$ \\
\hline Ruhnu 3 & $7.3 \pm 0.1$ & 170 & $1.14 \pm 0.01$ & $2.02 \pm 0.04$ & $0.37 \pm 0.06$ & $0.48 \pm 0.01$ & - & $164 \pm 16$ & $2.13 \pm 0.11$ \\
\hline Ruhnu 4 & $8.1 \pm 0.1$ & 180 & $0.85 \pm 0.01$ & $2.13 \pm 0.05$ & $0.11 \pm 0.03$ & $0.58 \pm 0.01$ & loss? & $162 \pm 16$ & $1.91 \pm 0.09$ \\
\hline Ruhnu 5 & $12.4 \pm 0.1$ & 170 & $1.13 \pm 0.01$ & $1.22 \pm 0.07$ & $0.40 \pm 0.14$ & $0.42 \pm 0.02$ & - & $165 \pm 17$ & $2.05 \pm 0.11$ \\
\hline Ruhnu 6 & $12.7 \pm 0.1$ & 185 & $1.00 \pm 0.01$ & $1.06 \pm 0.14$ & $0.09 \pm 0.12$ & $0.38 \pm 0.02$ & loss? & $160 \pm 16$ & $1.91 \pm 0.10$ \\
\hline Ruhnu 7 & $11.8 \pm 0.1$ & 185 & $0.69 \pm 0.01$ & $1.33 \pm 0.12$ & $0.35 \pm 0.09$ & $0.43 \pm 0.02$ & - & $161 \pm 15$ & $1.68 \pm 0.09$ \\
\hline Ruhnu 8 & $12.6 \pm 0.1$ & 170 & $0.47 \pm 0.01$ & $7.94 \pm 0.29$ & $1.25 \pm 0.17$ & $1.36 \pm 0.02$ & - & $165 \pm 16$ & $1.95 \pm 0.11$ \\
\hline Ruhnu 9 & $18.1 \pm 0.1$ & 215 & $2.04 \pm 0.02$ & $5.50 \pm 0.15$ & $1.17 \pm 0.38$ & $1.23 \pm 0.05$ & - & $155 \pm 16$ & $3.31 \pm 0.17$ \\
\hline Ruhnu 10 & $14.3 \pm 0.1$ & 120 & $0.70 \pm 0.01$ & $2.92 \pm 0.11$ & $0.95 \pm 0.10$ & $0.73 \pm 0.02$ & - & $176 \pm 18$ & $1.88 \pm 0.10$ \\
\hline Ruhnu 11 & $12.5 \pm 0.1$ & 355 & $0.68 \pm 0.01$ & $1.16 \pm 0.09$ & $0.45 \pm 0.04$ & $0.39 \pm 0.01$ & - & $129 \pm 13$ & $1.62 \pm 0.08$ \\
\hline
\end{tabular}
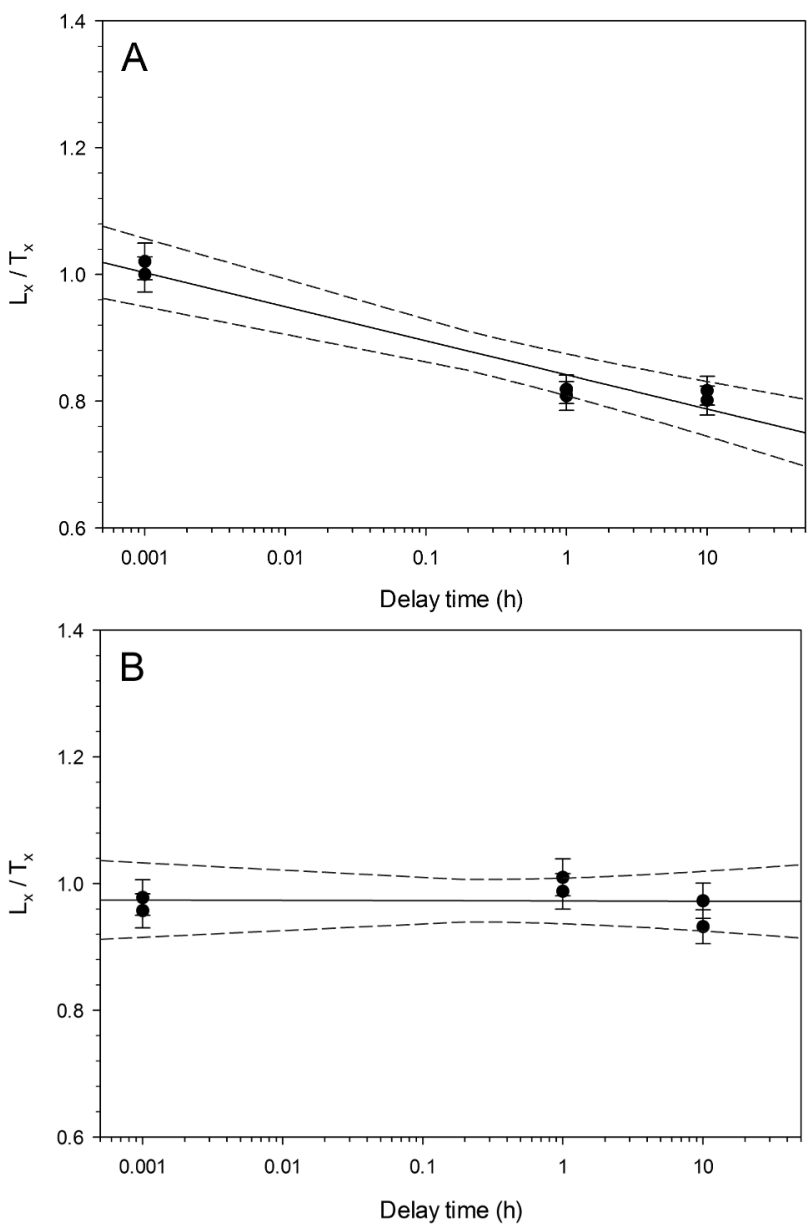

Fig. 3. Examples of fading tests for sample Ruhnu-4. A) Shows the results of the signal loss with increasing delay time between irradiation and measurement for IRSL at $50^{\circ} \mathrm{C}$ and $B$ ) for post-IR-IRSL measured at $150^{\circ} \mathrm{C}$ for the same aliquot, corresponding to $5.0 \pm 0.5$ and $0.0 \pm 0.6 \mathrm{~g}$, respectively.
Table 3. Fading rates determined for sample Ruhnu 4.

\begin{tabular}{cc}
\hline Method & $\mathbf{g}(\%$ per decade $)$ \\
\hline IRSL 50/150 & $5.0 \pm 0.5$ \\
\hline post-IR-IRSL 150 & $0.0 \pm 0.6$ \\
\hline IRSL 50/225 & $5.9 \pm 0.6$ \\
\hline post-IR-IRSL 225 & $-0.5 \pm 0.4$ \\
\hline IRSL 50/290 & $4.8 \pm 2.5$ \\
\hline post-IR-IRSL 290 & $0.3 \pm 0.4$
\end{tabular}

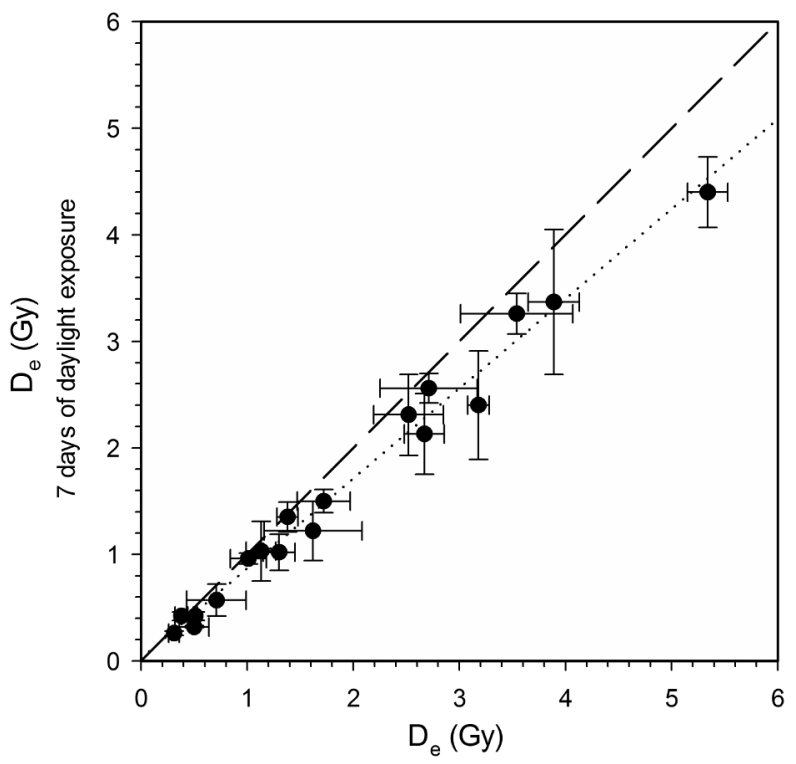

2 days of daylight exposure

Fig. 4. Comparison of residual doses for different methods after two and seven days of daylight exposure. This comparison reveals that the prolonged daylight exposure leads to systematic but only slightly lower residual $D_{e}$ values. 


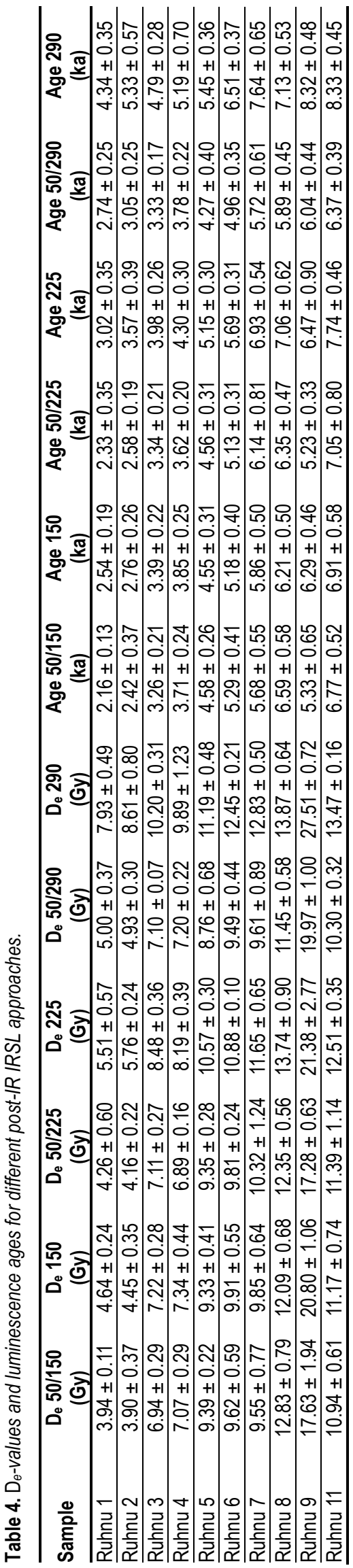

There is also a clear tendency for higher post IR-IRSL $\left(290^{\circ} \mathrm{C}\right) D_{\mathrm{e}}$-values compared to post-IR-IRSL $\left(150^{\circ} \mathrm{C}\right)$ (Fig. 4D). The difference between the two approaches is most prominent for the youngest two samples, where the high temperature approach is $70-90 \%$ higher, whereas for the older samples the difference is only $15-35 \%$.

The fact that non-fading corrected IRSL $\left(50^{\circ} \mathrm{C}\right)$ and post-IR-IRSL $\left(150^{\circ} \mathrm{C}\right)$ give almost identical ages is unexpected, as large differences have been found in the fading experiments. This implies that the signal loss observed in the experiments does not represent the fading of the signal over geological periods. Similar conclusions have been reported by other authors (e.g. Wallinga et al., 2007; Thiel et al., 2011; Kars et al., 2012; Lowick et al., 2012; Gaar and Preusser, 2012) and raise general concerns about the suitability of fading correction. As a consequence, we refrain from carrying out any kind of fading correction for the samples under consideration.

The results of the bleaching experiments are given in Table 5. These experiments show only a slight but systematic difference between the results determined for two and seven days of daylight exposure (Fig. 5). For example, the residual dose for Ruhnul of IRSL $\left(50^{\circ} \mathrm{C}\right)$ of the post-IR-IRSL $\left(150^{\circ} \mathrm{C}\right)$ protocol is $0.31 \pm 0.05 \mathrm{~Gy}$ after two days and $0.26 \pm 0.02$ Gy after seven days. For same sample the residual for post-IR-IRSL $\left(290^{\circ} \mathrm{C}\right)$ is $3.54 \pm 0.53 \mathrm{~Gy}$ and $3.26 \pm 0.19 \mathrm{~Gy}$, respectively. For the same approach, the residual of sample Ruhnu9 is $5.34 \pm 0.19$ Gy (two days) and $4.40 \pm 0.33$ Gy (seven days). This relationship between the residual dose and the relative age of the samples applies to the entire data set. The values for the stratigraphic younger sample Ruhnu-1 are systematically lower than for the older sample Ruhnu9. This implies that the easy-to-bleach signal component has been removed and the determined $D_{\mathrm{e}}$-values are likely representing likely the effect of slow-to-bleach components and/or thermal transfer. Similar observations have been made by Li et al. (2013), who observed an increase of residuals with increasing stimulation temperature and emphasise that the residual dose associated with the nonbleachable component is highly variable from sample to sample. The results presented here confirm the first observation and further highlight that even for sediments that are usually considered as well-bleached, such as the aeolian sand derived from beach deposits of our study, the residual might be important, at least for high temperature approaches. For the samples investigated here, the residual dose approaches $50 \%$ of the measured natural dose for post-IR-IRSL $\left(290^{\circ} \mathrm{C}\right)$ and is only $5 \%$ for postIR-IRSL $\left(150^{\circ} \mathrm{C}\right)$ in the youngest sample. Li et al. (2013) have stressed that ignoring residuals or simply subtracting them from the measured $D_{\mathrm{e}}$ is both inappropriate, and these authors have suggested a dose-subtraction procedure. Unfortunately, due to the shortage of feldspar grains in our samples, it was not possible to test this procedure in this study. 

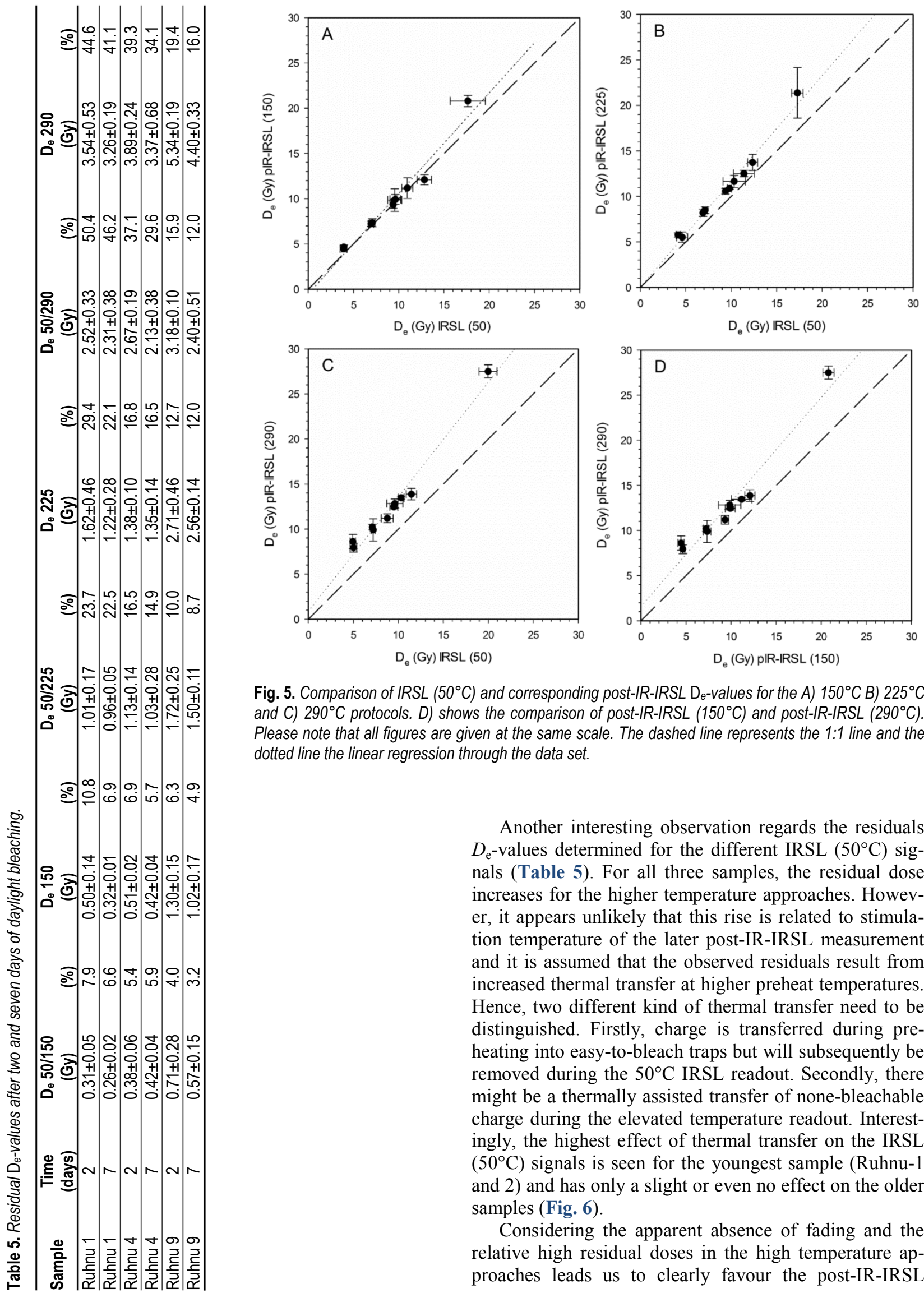

Fig. 5. Comparison of $I R S L\left(50^{\circ} \mathrm{C}\right)$ and corresponding post-IR-IRSL De-values for the A) $\left.150^{\circ} \mathrm{C} \mathrm{B}\right) 225^{\circ} \mathrm{C}$ and C) $290^{\circ} \mathrm{C}$ protocols. D) shows the comparison of post-IR-IRSL $\left(150^{\circ} \mathrm{C}\right)$ and post-IR-IRSL $\left(290^{\circ} \mathrm{C}\right)$. Please note that all figures are given at the same scale. The dashed line represents the 1:1 line and the dotted line the linear regression through the data set.

Another interesting observation regards the residuals $D_{\mathrm{e}}$-values determined for the different IRSL $\left(50^{\circ} \mathrm{C}\right)$ signals (Table 5). For all three samples, the residual dose increases for the higher temperature approaches. However, it appears unlikely that this rise is related to stimulation temperature of the later post-IR-IRSL measurement and it is assumed that the observed residuals result from increased thermal transfer at higher preheat temperatures. Hence, two different kind of thermal transfer need to be distinguished. Firstly, charge is transferred during preheating into easy-to-bleach traps but will subsequently be removed during the $50^{\circ} \mathrm{C}$ IRSL readout. Secondly, there might be a thermally assisted transfer of none-bleachable charge during the elevated temperature readout. Interestingly, the highest effect of thermal transfer on the IRSL $\left(50^{\circ} \mathrm{C}\right)$ signals is seen for the youngest sample (Ruhnu-1 and 2) and has only a slight or even no effect on the older samples (Fig. 6).

Considering the apparent absence of fading and the relative high residual doses in the high temperature approaches leads us to clearly favour the post-IR-IRSL 


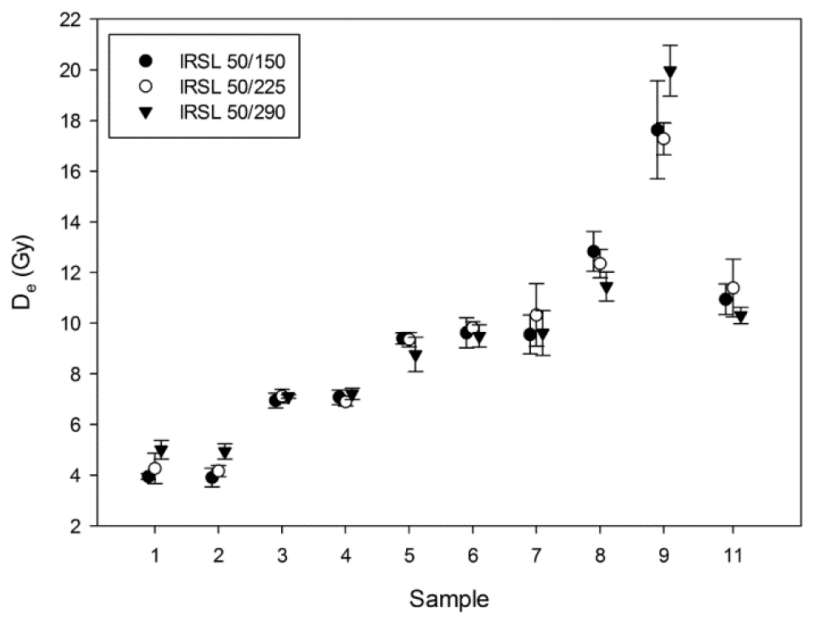

Fig. 6. Comparison of IRSL $\left(50^{\circ} \mathrm{C}\right) \mathrm{D}_{e}$-values determined for different samples and protocols.

$\left(150^{\circ} \mathrm{C}\right)$ approach for the studied sediments. Even for this approach, however, it is difficult to judge the potential effect of residuals on the determined ages. While the samples have been exposed to daylight for several days, natural light exposure might have been even more effective due to repeated reworking and deposition cycles that occur in the coastal environments. As a result, a slow-tobleach component might have been more effectively reset in nature than under experimental conditions. Hence, the post-IR-IRSL $\left(150^{\circ} \mathrm{C}\right)$ ages without applying any correction are used in the following discussion of the age of the dune sequence. A potential overestimation of the ages is expected to not exceed a few hundred years.

\section{Chronology of foredune accumulation on Ruhnu Is- land}

Samples from Ruhnu-8 to Ruhnu-1 represent a sequence of straight shore-parallel foredune ridges formed in the condition of lowering relative sea level. The oldest sample (Ruhnu-11) is dated to $6.91 \pm 0.58 \mathrm{ka}$ and the ages get successively younger with decreasing elevation above sea level with the youngest of the foredunes being dated to $2.54 \pm 0.19 \mathrm{ka}$. For comparison with the luminescence ages determined for the foredune sequence two radiocarbon dates are available, which have been calibrated with the OxCal program (Bronk Ramsey, 2009) using the IntCal13 curve (Reimer et al., 2013), and are reported at 2-sigma level. A buried oak trunk was found in Litorina Sea beach sediments directly below the foredune ridge corresponding to sample Ruhnu-4 (R_C2 in Fig. 1C). This oak was oriented perpendicular to the former position of the shoreline and it appears most likely that its burial was associated to coastal erosion and related sediment accumulation. The youngest tree rings of the oak trunk were radiocarbon dated to 3.99-3.72 cal ka BP $\left(3580 \pm 40{ }^{14} \mathrm{C}\right.$ yr), which is in excellent agreement with the post-IR-IRSL $\left(150^{\circ} \mathrm{C}\right)$ age of $3.85 \pm 0.25 \mathrm{ka}$, while other approaches yield ages either younger or older than the radiocarbon age. The basal part of a $1.08 \mathrm{~m}$ thick peat layer in the swale seaward from the foredune of the sample Ruhnu-6 (R_C1 in Fig. 1C) was radiocarbon dated to $3.06-2.87 \mathrm{cal} \mathrm{ka}$ BP $\left(2840 \pm 30{ }^{14} \mathrm{C} \mathrm{yr}\right)$. This age is $c$. 2.2 ka younger than Ruhnu- 6 and c. 1.6 ka younger than Ruhnu-5. This radiocarbon age gives the younger limiting age for the seaward foredune ridge and does not reflect the formation time of this ridge. Thus, it seems that the hydrological conditions were not favourable for peat accumulation in this swale directly after the formation of seaward foredunes.

Previous studies on Holocene relative sea level change from the Gulf of Riga provide indirect verification of the proposed chronology of foredune accumulation based on the post-IR-IRSL $\left(150^{\circ} \mathrm{C}\right)$ ages. Radiocarbon ages from the Pärnu Bay area (Rosentau et al., 2011) and Saaremaa Island (Saarse et al., 2009) show that the highest shoreline of the Litorina Sea formed around 7.3 cal ka BP. Its maximum elevation, which varies due to the differential isostatic uplift in the area, has been estimated to about 9-10 $\mathrm{m}$ a.s.l. around Ruhnu Island (Fig. 1B). Sample Ruhnu-11, which is taken from the centremost foredune ridge, with its post-IR-IRSL $\left(150^{\circ} \mathrm{C}\right)$ age $6.91 \pm 0.58 \mathrm{ka}$ and altitude $8.95 \mathrm{~m}$ a.s.l. fits relatively well with the radiocarbon age of the Litorina Sea maximum stand. On the top of the centremost foredune ridge four charcoal samples from Late Mesolithic fireplaces (Fig. 1C) have been radiocarbon dated and the oldest age was 7.61-6.91 cal ka BP $\left(6400 \pm 170{ }^{14} \mathrm{C}\right.$, Kriiska and Lõugas, 2005), providing additional older limiting age for sample Ruhnu-11.

The ages obtained for Ruhnun Island indicate systematic progradation of the beach with average rate of $c$. $0.38 \mathrm{~m}$ per year being in good agreement with data from relative sea level studies by Saarse et al. (2009) and Rosentau et al. (2011). A similar shore-parallel Litorina Sea foredune sequence has been OSL dated using quartz in NE Estonia (Rosentau et al., 2013). These results show that continuous beach progradation during the Litorina Sea regression period has been interrupted by an episode of foredune instability around $5.4 \pm 0.9 \mathrm{ka}$ ago. Such a disruption in the foredune sequence is not observed on Ruhnu Island.

\section{CONCLUSIONS}

This study has shown that differences in fading rates observed experimentally may not necessary reflect the natural stability of IRSL and post-IR-IRSL signals. Hence, procedures to correct for fading should be considered with care. It has also been demonstrated that bleaching experiments reveal residual $D_{\mathrm{e}}$-values that can have a significant effect on age calculation for at least some of the post-IR IRSL approaches. According to our investigations, the post-IR-IRSL $\left(150^{\circ} \mathrm{C}\right)$ approach is best suited to date the foredune sequence from Ruhnu Island, with 
the effect of residuals likely having an effect not exceeding a few hundred for the samples under consideration. The post-IR-IRSL $\left(150^{\circ} \mathrm{C}\right)$ ages decrease with elevation, as to be expected, and are in agreement with the available, though very limited, independent control given by two radiocarbon ages. This gives further confidence in the accuracy of the dating results and advocates the use of post-IR-IRSL with a stimulation temperature of $150^{\circ} \mathrm{C}$ for similar studies, where quartz OSL is not suitable.

\section{ACKNOWLEDGMENTS}

The help of Jenny Wolff in preparing the sample is kindly acknowledged. Gamma spectrometric measurements were carried out by Sönke Szidat, University of Bern, Switzerland. This study was financially supported by the Estonian Research Council grants ETF9011 and PUT456 and COST Action T00902.

\section{REFERENCES}

Adamiec G and Aitken M, 1998. Dose-rate conversion factors: update. Ancient TL 16: 37-50.

Andrén T, Björck S, Andren E, Conley LZ and Anjar J, 2011. The development of the Baltic Sea Basin during the Last $130 \mathrm{ka}$. In: Harff J, Björck S and Hoth P, eds., The Baltic Sea Basin. Central and Eastern European Development Studies, Springer, Berlin: 7597.

Auclair M, Lamothe M and Huot S, 2003. Measurement of anomalous fading for feldspar IRSL using SAR. Radiation Measurements 37(4-5): 487-492, DOI 10.1016/S1350-4487(03)00018-0.

Bronk Ramsey C, 2009. Bayesian analysis of radiocarbon dates. Radiocarbon 51: 337-360.

Buylaert JP, Murray AS, Thomsen KJ and Jain M, 2009. Testing the potential of an elevated temperature IRSL signal from K-feldspar. Radiation Measurements 44(5-6): 560-565, DOI 10.1016/j.radmeas.2009.02.007.

Ekman M, 1996. A consistent map of the postglacial uplift of Fennoscandia. Terra Nova 8(2): 158-165, DOI 10.1111/j.13653121.1996.tb00739.x.

Gaar D and Preusser F, 2012. Luminescence dating of mammoth remains from northern Switzerland. Quaternary Geochronology 10: 257-263, DOI 10.1016/j.quageo.2012.02.007.

Hesp P, 2002. Foredunes and blow outs: initiation, geomorphology and dynamics. Geomorphology 48(1-3): 245-268, DOI 10.1016/S0169-555X(02)00184-8.

Huntley DJ and Lamothe M, 2001. Ubiquity of anomalous fading in Kfeldspars and the measurement and correction for it in optical dating. Canadian Journal of Earth Sciences 38(7): 1093-1106, DOI 10.1139/e01-013.

Jain M and Ankjærgaard C, 2011. Towards a non-fading signal in feldspar: Insight into charge transport and tunnelling from timeresolved optically stimulated luminescence. Radiation Measurements 46(3): 292-309, DOI 10.1016/j.radmeas.2010.12.004.

Kala E and Einasto R, 1979. Liivi lahe piirkonna geoloogiline ehitus ja areng. (Geology and development of the Gulf of Riga region). Eesti Loodus 11: 708-711 (in Estonian).

Kars RH, Busschers FS and Wallinga J, 2012. Validating post IR-IRSL dating on K-feldspars through comparison with quartz OSL ages. Quaternary Geochronology 12: 74-86, DOI 10.1016/j.quageo.2012.05.001.

Kask J, Lepland A and Perens R, 1994. Geology of the Island of Ruhnu from the remote past up to date. Eesti TA Geoloogia Instituut and Eesti Geoloogiakeskus, Tallinn-Kuressaare (in Estonian with English summary).
Kriiska A and Lõugas L, 2005. Formation of Ruhnu Island and its early settlement history. Estonia Maritima 7: 119-132.

Kulig G, 2005. Erstellung einer Auswertesoftware zur Altersbestimmung mittels Lumineszenzverfahren. BSc thesis, Faculty of Mathematics and Informatics TU Freiberg, Germany (unpublished).

Li B and Li S-H, 2011. Luminescence dating of K-feldspar from sediments: A protocol without anomalous fading correction. Quaternary $\quad$ Geochronology 6: 468-479, $\quad$ DOI 10.1016/j.quageo.2011.05.001.

Li B, Roberts RG and Jacobs Z, 2013. On the dose dependency of the bleachable and non-bleachable components of IRSL from Kfeldspar: Improved procedures for luminescence dating of Quaternary sediments. Quaternary Geochronology 17: 1-13, DOI 10.1016/j.quageo.2013.03.006.

Lowick SE, Trauerstein M and Preusser F, 2012. Testing the application of post IR-IRSL dating to fine grain waterlain sediments. Quaternary Geochronology $\quad 8: \quad 33-40, \quad$ DOI 10.1016/j.quageo.2011.12.003.

Madsen AT, Buylaert JP and Murray AS, 2011. Luminescence dating of young coastal deposits from New Zealand using feldspar. Geochronometria 38(4): 379-390, DOI 10.2478/s13386-011-0042-5.

Olley JM, Roberts RG and Murray AS, 1997. Disequilibria in the uranium decay series in sedimentary deposits at Allen's Cave, Nullarbor Plain, Australia: Implications for dose rate determinations. Radiation Measurements 27(2): 433-443, DOI 10.1016/S1350-4487(96)00114-X.

Prescott J and Hutton JT, 1994. Cosmic ray contributions to dose rates for luminescence and ESR dating: Large depths and long-term time variations. Radiation Measurements 23(2-3): 497-500, DOI 10.1016/1350-4487(94)90086-8.

Preusser F and Kasper HU, 2001. Comparison of dose rate determination using high-resolution gamma spectrometry and inductively coupled plasma-mass spectrometry. Ancient TL 19: 19-24.

Preusser F, Ramseyer K and Schlüchter C, 2006. Characterisation of low OSL intensity quartz from the New Zealand Alps. Radiation Measurements $\quad 41(7-8): \quad 871-877, \quad$ DOI 10.1016/j.radmeas.2006.04.019.

Reimann T, Tsukamoto S, Naumann M and Frechen M, 2011. The potential of using K-rich feldspars for optical dating of young coastal sediments - a test case from Darss-Zingst peninsula (southern Baltic Sea coast). Quaternary Geochronology 6: 207222, DOI 10.1016/j.quageo.2010.10.001.

Reimann T and Tsukamoto S, 2012. Dating the recent past ( $<500$ years) by post-IR IRSL feldspar - Examples from the North Sea and Baltic Sea coast. Quaternary Geochronology 10: 180-187, DOI 10.1016/j.quageo.2012.04.011.

Reimer PJ, Bard E, Bayliss A, Beck JW, Blackwell PG, Bronk Ramsey C, Grootes PM, Guilderson TP, Haflidason H, Hajdas I, Hatte C, Heaton TJ, Hoffmann DL, Hogg AG, Hughen KA, Kaiser K F, Kromer B, Manning SW, Niu M, Reimer RW, Richards DA, Scott EM, Southon JR, Staff RA, Turney CSM and van der Plicht J, 2013. IntCal13 and Marine13 Radiocarbon Age Calibration Curves 0-50,000 Years cal BP. Radiocarbon 55: 1869-1887.

Richter D, Pintaske R, Dornich K and Krbetscheck M, 2012. A novel beta source design for uniform irradiation in dosimetric application. Ancient TL 30: 57-63.

Richter D, Richter A and Dornich K, 2013. Lexsyg - A new system for luminescence research. Geochronometria 40(4): 220-228, DOI 10.2478/s13386-013-0110-0.

Rosentau A, Veski S, Kriiska A, Aunap R, Vassiljev J, Saarse L, Hang T, Heinsalu A and Oja T, 2011. Palaeogeographic model for the SW Estonian coastal zone of the Baltic Sea. In: Harff J, Björck S and Hoth P, eds., The Baltic Sea Basin. Central and Eastern European Development Studies, Springer, Berlin: 165-188.

Rosentau A, Joeleht A, Plado J, Aunap R, Muru M and Eskola KO, 2013. Development of the Holocene foredune plain in the NarvaJoesuu area, eastern Gulf of Finland. Geological Quarterly 57(1): 89-100, DOI 10.7306/gq.1077.

Saarse L, Vassiljev J and Miidel A, 2003. Simulation of the Baltic Sea shorelines in Estonia and neighbouring areas. Journal of Coastal Research 19: 261-268. 
Saarse L, Vassiljev J, Miidel A and Niinemets E, 2006. Holocene buried organic sediments in Estonia. Proceedings Estonian Academy of Sciences - Geology 55: 296-320.

Saarse L, Vassiljev J and Rosentau A, 2009. Ancylus Lake and Litorina Sea transition on the Island of Saaremaa, Estonia: a pilot study. Baltica 22: 51-62.

Steffen D, Preusser F and Schlunegger F, 2009. OSL quartz age underestimation due to unstable signal components. Quaternary Geochronology 4(5): 353-362, DOI 10.1016/j.quageo.2009.05.015.

Thiel C, Buylaert JP, Murray A, Terhorst B, Hofer I, Tsukamoto S and Frechen M, 2011. Luminescence dating of the Stratzing loess profile (Austria) - Testing the potential of an elevated temperature post-IR IRSL protocol. Quaternary International 234(1-2): 23-31, DOI 10.1016/j.quaint.2010.05.018.

Thomsen KJ, Murray AS, Jain M and Bøtter-Jensen L, 2008. Laboratory fading rates of various luminescence signals from feldspar-rich sediment extracts. Radiation Measurements 43(9-10): 1474-1486,
DOI 10.1016/j.radmeas.2008.06.002.

Veski S, Heinsalu A, Klassen V, Kriiska A, Lõugas L, Poska A and Saluäär U, 2005. Early Holocene coastal settlement and palaeoenvironment on the shore of the Baltic Sea at Pärnu, southwestern Estonia. Quaternary International 130(1): 75-85, DOI 10.1016/j.quaint.2004.04.033

Wallinga J, Bos AJJ, Dorenbos P, Murray AS and Schokker J, 2007. A test case for anomalous fading correction in IRSL dating. Quaternary Geochronology 2(1-4): 216-221,

DOI 10.1016/j.quageo.2006.05.014.

Wintle AG, 1973. Anomalous fading of thermo-luminescence in mineral samples. Nature 245: 143-144, DOI 10.1038/245143a0.

Zander A, Degering D, Preusser F, Kasper HU and Brückner H, 2007. Optically stimulated luminescence dating of sublittoral and intertidal sediments from Dubai, UAE.: Radioactive disequilibria in the uranium decay series. Quaternary Geochronology 2(1-4): 123128, DOI 10.1016/j.quageo.2006.04.003. 